Provided for non-commercial research and education use. Not for reproduction, distribution or commercial use.

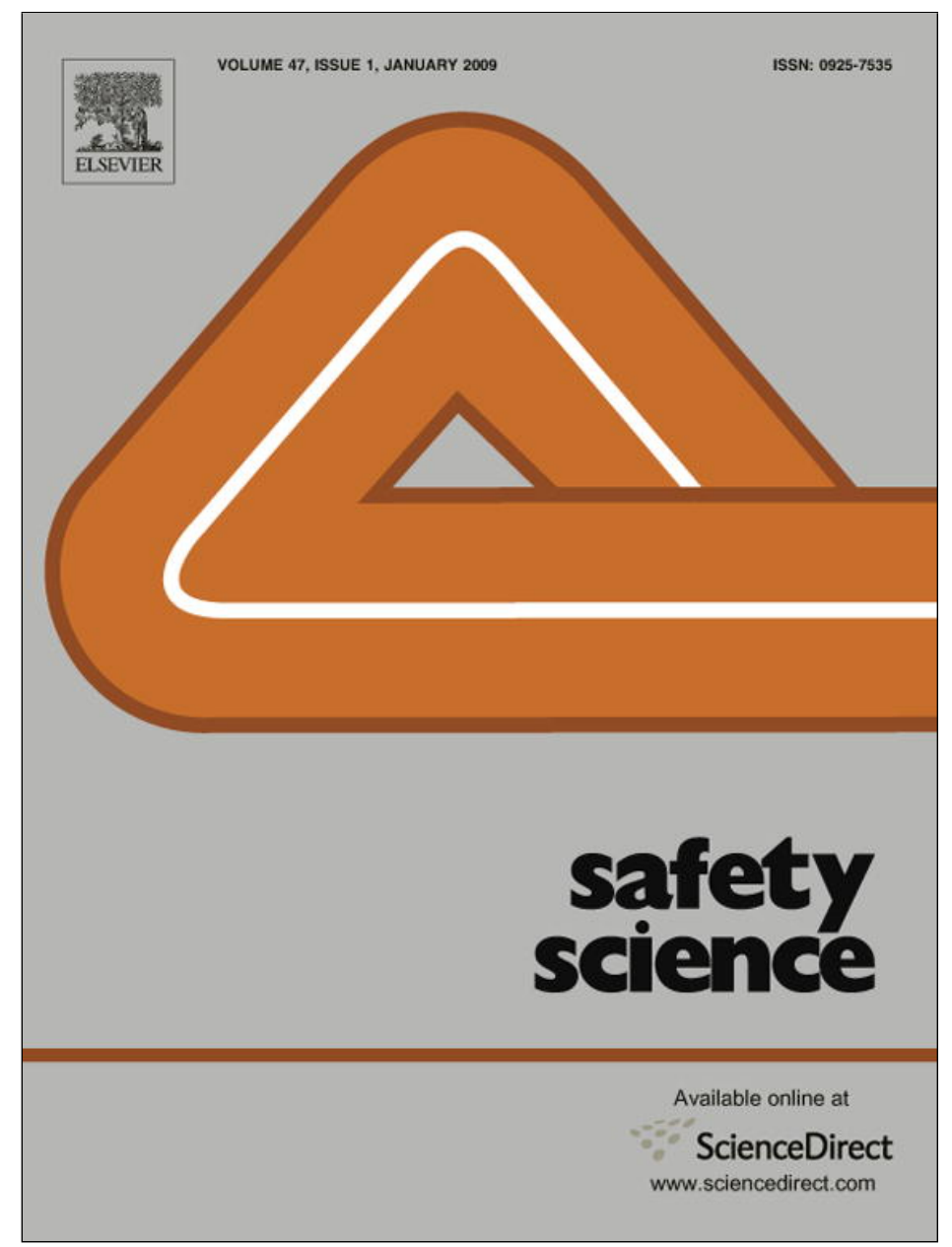

This article appeared in a journal published by Elsevier. The attached copy is furnished to the author for internal non-commercial research and education use, including for instruction at the authors institution and sharing with colleagues.

Other uses, including reproduction and distribution, or selling or licensing copies, or posting to personal, institutional or third party websites are prohibited.

In most cases authors are permitted to post their version of the article (e.g. in Word or Tex form) to their personal website or institutional repository. Authors requiring further information regarding Elsevier's archiving and manuscript policies are encouraged to visit:

http://www.elsevier.com/copyright 


\title{
Educational status and organizational safety climate: Does educational attainment influence workers' perceptions of workplace safety?
}

\author{
Seth A. Gyekye ${ }^{\mathrm{a}, *}$, Simo Salminen ${ }^{\mathrm{b}}$ \\ a Anglia Ruskin University, Department of Psychology, East Road, Cambridge CB1 1PT, UK \\ ${ }^{\mathrm{b}}$ Finnish Institute of Occupational Health, Safety Department, Helsinki, Finland
}

Received 31 May 2007; received in revised form 15 October 2007; accepted 17 December 2007

\begin{abstract}
From a practical perspective, understanding the impact of education on perceptions of workplace safety would benefit management's decisions regarding workers' adaptability, general work effectiveness, accident frequency, implementation of safety management policies, and handling of education-related accident characteristics. The current study thus examined the relationship between educational attainment and (i) safety perception, (ii) job satisfaction, (iii) compliance with safety management policies, and (iv) accident frequency. Participants were Ghanaian industrial workers $(N=320)$ categorized into four educational groups based on their responses: basic education $50 \%(n=159)$; secondary education, $n=98(30 \%)$; vocational/professional education, $17 \%(n=56)$; and university education, $3 \%$ $(n=7)$. Workplace safety perception was assessed with Hayes et al.'s 50-item Work Safety Scale (WSS): a scale that effectively captures the dimensions identified by safety experts to influence perceptions of workplace safety. Multivariate analysis (MANOVA) was used to test for differences of statistical significance. Posterior comparison with $t$-test consistently revealed significant differences between the two higher-educated cohorts and their lower-educated counterparts. The results indicated a positive association between education and safety perception. Higher-educated workers recorded the best perceptions on safety, indicated the highest level of job satisfaction, were the most compliant with safety procedures and recorded the lowest accident involvement rate.
\end{abstract}

(C) 2008 Elsevier Ltd. All rights reserved.

Keywords: Education; Safety perception; Accident frequency; Job satisfaction; Safety management

\section{Introduction}

Research on perception of workplace safety began in the early 1980s with Zohar's (1980) ubiquitous study and has since received considerable attention in organizational and psychological literature. These shared perceptions about safety values, norms, beliefs, practices, and principles of workers in their work environments have been technically termed safety climate (Cooper and Phillips, 2003; Silva et al., 2004). The importance of safety perception sur-

\footnotetext{
* Corresponding author. Tel.: +1 845196 2645; GSM: 070810266901

E-mail addresses: s.gyekye@anglia.ac.uk, sgyekye@welho.com (S.A Gyekye).
}

veys can be gleaned from the literature (e.g., Cooper and Phillips, 2003; Silva et al., 2004). First, as leading indicators of safety performance, they have helped in the identification of precursors to accident occurrence, and by so doing, effectively decreased accident occurrence. Second, by providing proactive information about safety problems before they develop into accidents and injuries, safety perception analyses have provided guidance to management in developing specific safety programs. Third, compared to other proactive means of accident prevention, safety perception analyses are relatively inexpensive. Finally, they have provided information about safety management from employees' perspectives. With specific reference to the current study, exploring the impact of educational attainment in 
a safety climate analysis could provide a potent proactive safety management tool, as they could indicate a need for special safety programs for a particular group.

Given the critical importance of safety climate in the work environment, the extent to which safety perceptions differ in different work groups, companies and institutions have been meticulously examined for the past 30 years. Examples of such studies include DeJoy et al.'s (1995) analyses in health care settings, Diaz and Cabrera's (1997) analyses on airport ground handling operations, and Niskanen's study (1994) in road administration. Additionally, comparative analyses between managers' and employees' perceptions (Prussia et al., 2003), high- and low-accident organizations (Zohar, 2000), individual-level and organizational-level climate perceptions (Hofmann and Stetze, 1998; Zohar and Luria, 2003) and between blue-collar workers and white-collar workers (Morris et al., 1999) have been carried out. Basically, what most of these studies revealed is that workers differ in their attitudes to safety issues and in their perceptions of workplace hazards.

A body of evidence thus exist which links safety perception to safety performances (Cooper and Phillips, 2003; Hofmann and Stetze, 1998), accident frequency (Guastello, 1999), job satisfaction (Gyekye, 2005), compliance with safety management polices (Gyekye, 2005; Probst, 2002; Probst and Brubaker, 2001), and work environment (DeJoy et al., 2004; Gyekye, 2006). The assumption that workers' demographical variables, particularly cognitive ability (education), job experience and age are major determinants of accident risk and safety permeates the accident and safety literature (e.g., Carder and Ragan, 2003; Hansen, 1989). While much attention has been given to employee age and job experience, the impact of formal education on accident involvement is neither straightforward nor well documented. Besides, there is lack of research regarding the relationship between workers' educational attainment and safety perception. This study was thus designed to address the paucity. Accordingly, it compared the safety perceptions of workers with four levels of educational attainment (basic, secondary, professional/vocational, and university education). Additional comparative analyses examined the relationship between these educational levels with (ii) job satisfaction, (iii) compliance with safety management policies, and (iv) accident frequency. The dearth in research on organizational behaviour in Africa constitutes another reason for these analyses.

\subsection{Educational attainment, accident frequencies and safety management}

In the literature, education is usually characterized as a learning process through which people acquire knowledge and information, the development of cognitive capacities, and the transfer of norms, values and modes of behaviour. It increases attention management, information processing capabilities, and enhances the cognitive abilities necessary for the successful analysis of otherwise sophisticated prob- lems. In effect, it provides insight into complex and multifaceted problems and thereby makes handling otherwise complicated issues manageable. A higher level of education will therefore promote strategic thinking, develop workers' perspectives to enable them systematically analyze, store, and rightly use information that is relevant for their job performances. From a cognitive-behavioural perspective, people have a set of cognitive resources which they use when engaged in a task (e.g., Döös et al., 2004; Kanfer and Ackerman, 1989). It is reasonable to assume therefore that workers' level of education would have important implications on the successful execution of their job assignments.

Numerous studies that have investigated the role of cognitive-intellectual abilities in predicting individual differences in job performance have found a substantial positive relationship between cognitive abilities and job performance (e.g., Dunnette, 1976; Ghiselli, 1966; Hunter, 1986). In an excellent review, Hunter (1986) reported that general cognitive ability predicts job performance in all jobs. With support from path analysis, he demonstrated that much of this predictive power stems from the fact that general cognitive ability predicts job knowledge $(r=.80)$ and job knowledge predicts job performance $(r=.80)$. Going by this reasoning, peoples' levels of education would be positively correlated with their safety and preventive behaviours, and inversely related to their accident involvement rate. However, a range of studies investigating the relationship between various cognitive abilities and accident frequency have produced conflicting results.

Accident and safety research has traditionally been done separately in three main sectors of safety, namely work, traffic, and home and leisure. Research findings regarding the relationship between educational attainment and accident frequency is limited and equivocal. Some researchers have found a positive relationship between education and accident frequency (e.g., Hansen, 1989; Iverson and Erwin, 1997). According to these experts, the higher-educated workers tend to possess greater skills which broaden their work responsibilities, and thereby increase their accident potential. By contrast, several high-ranking studies have reported the contrary. Others have noted that education does not by itself guarantee competency and effectiveness (e.g., Lourens et al., 1999; Owsley et al., 2004), and that there is no relationship between level of education and accident involvement. In a study among military recruits, O’Toole (1990) found the risk of mortality among lowereducated army recruits relatively higher than their highereducated counterparts. Lourens et al. (1999) did not find any relationship between level of education and accident frequency. No study was found on the link between educational attainment and compliance with safety management policies.

The relationship between educational level and job satisfaction, even though extensively researched and well documented, yet remains equivocal and contradictory. While some studies have documented a positive association between educational attainment and job satisfaction (e.g., 
Howard and Frink, 1996; Oshagbemi, 2003), others have reported a decrease in satisfaction as educational levels increased (e.g., Klien and Maher, 1966; Metle, 2003; Vollmer and Kinney, 1995). Other reports have found no association between educational attainment and job satisfaction (e.g., Gordon and Arvey, 1975; King et al., 1982). The inconsistencies and contradictions regarding this relationship have been confirmed and highlighted in a review by Oshagbemi (2003).

Drawing from the literature review above, it is reasonable to expect employees' educational attainment to effect differently on their safety perceptions, level of job satisfaction, compliance with safe work procedures and accident frequency. Thus the following propositions were formulated:

Proposition 1. Educational level and safety perception: Because of the absence of ample evidence that bears directly on the relationship between educational level and safety perception, this relationship is tested but no proposition is made regarding its direction.

Proposition 2. Educational level and job satisfaction: Despite the irregularities and inconsistencies in the research findings, it is anticipated that higher-educated workers would express more job satisfaction than their relatively lower-educated colleagues.

Proposition 3. Educational level and compliance with safety work policies: Because of the absence of ample evidence that bears directly on the relationship between education and compliance with safe work practices, this relationship is tested but no proposition is made regarding its direction.

Proposition 4. Educational level and accident frequency: Despite the irregularities and inconsistencies, it is anticipated that higher-educated workers would have fewer accidents, and vice versa.

\section{Method}

\subsection{Sample and procedure}

The participants were 320 Ghanaian industrial workers and comprised of the following characteristics: Sixty-five percent $(n=208)$ was male and $35 \%(n=112)$ female. Thirteen percent $(n=42)$ of all participants had been at the workplace for less than a year; $22 \%(n=70)$ between 1 and 4 years; $21 \%(n=67)$ between 5 and 10 years; $25 \%$ $(n=80)$ between 11 and 14 years; and 19\% $(n=61)$ over 15 years. Regarding age, $22 \%(n=70)$ of the workers were between 18 and 29 years; $25 \%(n=80)$ between 30 and 39 years; $43 \%(n=134)$ between 40 and 49 years, and $10 \%$ $(n=32)$ was 50 years and above. The educational background of the participants was as follows: $50 \%(n=159)$ had basic education, 30\% $(n=98)$ had secondary education, $17 \%(n=56)$ had professional/vocational education, and $3 \%(n=7)$, university education.
A structured questionnaire was used in the assessment. The participants responded to the questionnaire interview during the lunch breaks. It was presented in English language, and where respondents with poor literacy skills had problems understanding English language, the services of an interpreter was sought and the local dialect was used. The duration varied from 15 to $20 \mathrm{~min}$, depending on the context in which they were conducted, and on respondents' level of education. The supervisors were English proficient and filled in the questionnaire on their own. To ensure accuracy of responses, particular on issues that related to noncompliant job behaviours and worker counterproductive behaviours, participants were assured of confidentiality and anonymity. It was stressed that no member of their organization was part of the study and that their organisations/management would not have access to any information provided. Statistical analyses of the data were carried out with the SAS Statistical Package, Version 8.2 (SAS Institute Inc., NC, USA).

\subsection{Measures, questionnaire scoring and reliability}

\subsubsection{Perceptions of safety climate}

Perceptions of safety climate were measured with the 50item Work Safety Scale (WSS) developed by Hayes et al. (1998). Participants responded on a five-point scale ranging from 1 (=not at all) to 5 (=very much). This instrument assesses employees' perceptions on work safety and measures 5 distinct constructs, each with 10 items: (i) job safety (sample item: "Safety programs are effective": $\alpha=.96$ ), (ii) co-workers safety (sample item: "Pay attention to safety rules": $\alpha=.80$ ), (iii) supervisor safety (sample item: "Enforces safety rules": $\alpha=.97$ ), (iv) management's commitment to safety (sample item: "Responds to safety concern": $\alpha=.94)$, (v) satisfaction with safety program (sample item: "Effective in reducing accidents": $\alpha=.86$ ).

\subsubsection{Educational level}

Educational levels were measured by participants' markings on the option that corresponded to their educational backgrounds. Response options were: (a) basic education (b) secondary/technical school (c) professional/vocational (d) university. Workers with basic and secondary educational background were categorized as lower-educated, and their counterparts with vocational/professional and university education, higher-educated workers.

\subsubsection{Job satisfaction}

Job satisfaction was measured with Porter and Lawler's (1968) one-item global measure of job satisfaction. This measure was chosen because single-item measures of overall job satisfaction have been considered to be more robust than scale measures (Wanous et al., 1997). Besides, it has been used extensively in the organizational behaviour literature (e.g., Gyekye and Salminen, 2006; Harter et al., 2002). The measure has five response categories ranging from "extremely dissatisfied" to "extremely satisfied", 
corresponding to our five-point response format 1 (=not at all) to 5 (=very much).

\subsubsection{Items for compliance with safe work procedures}

Items for compliance with safe work procedures were pooled from the extant literature and comprised of the following four questions: "Follow safety procedures regardless of the situation", "Encourage co-workers to be safe", "Use appropriate tools and equipment", "Follow the correct procedure". Participants responded on a five-point scale ranging from 1 (=not at all) to 5 (=very much). Coefficient $\alpha$ was. 80 .

\subsubsection{Accident frequency}

Accident frequency was measured by participants' responses to the question that asked them to indicate the number of times they have been involved in accidents in the past 12 months. All reported cases were verified from the records and were accidents classified as serious by the safety inspection authorities.

\section{Results}

The propositions focused on the relationships between educational attainment, safety perception, job satisfaction, and safe work behaviour and accident frequency. Table 1 shows the intercorrelations and the high dependence of the five dimensions of the WSS.

As reflected on the table, while work safety and other dimensions are negatively correlated, the remaining correlations are positive. A plausible explanation could be that work safety assesses workers' own safety practices, while the other dimensions assess others' (supervisors', co-workers', managements') safety practices. The interaction effect between formal education and informal education was investigated and presented in Table 2. As reflected, the table shows a highly significant connection between the education and work experience of the workers $\left(\chi^{2}=\right.$ $242.66, \mathrm{df}=12, p<.001)$. The higher education the worker had, the more experienced he/she was on the job.

Three sets of analyses were performed. First an ANOVA computation indicated the item-by-item comparative analysis presented on Table 3 .

Second, because education, job role and experience are strongly interrelated, as shown by status-attainment models (e.g., Blau and Duncun, 1967), it was necessary to estimate the effect of educational attainment in a multivariate

Table 1

Intercorrelations of the Work Safety Scale

\begin{tabular}{|c|c|c|c|c|c|}
\hline & 1 & 2 & 3 & 4 & 5 \\
\hline 1. Work safety & 1 & & & & \\
\hline 2. Co-worker safety & $-.77^{* * *}$ & & & & \\
\hline 3. Supervisor safety & $-.82^{* * *}$ & $.82^{* * *}$ & & & \\
\hline 4. Management safety practices & $-.68^{* * *}$ & $.68^{* * *}$ & $.83^{* * *}$ & & \\
\hline 5. Safety programs & $-.81^{* * *}$ & $.77^{* * *}$ & $.87^{* * *}$ & $.80^{* * *}$ & \\
\hline
\end{tabular}

analysis (MANOVA), controlling for the effects of job role, and work experience. A three-factor analysis of variance with three between-subject factors (education, job role and experience) was highly significant with work safety $(F(28,255)=19.39, p<.001)$. A main effect of education occurred $(F(3,255)=118.55, p<.001)$, indicating that the higher-educated subjects evaluated work safety more than their lower-educated counterparts. A main effect of experience also occurred $(F(4,255)=35.57, p<.001)$, showing that experienced workers assessed work safety better than inexperienced workers. There was no main effect of job role $(F(1,355)=1.42$, n.s. $)$. However, the interaction effect of all three factors $(F(3,255)=3.01, p<.05)$ was significant. Regarding co-worker safety, the three-factor analysis of variance was also highly significant $(F(26,249)=$ $15.01, p<.001)$. The main effects of education $(F(3$, $249)=89.09, p<.001)$ and experience $(F(4,249)=23.39$, $p<.001)$ were highly significant, but not that of job role $(F(1,249)=1.46$, n.s. $)$. The interaction effect of three factors was not significant $(F(1,249)=0.11$, n.s. $)$. Thus the higher-educated and more experienced workers highly appraised the contribution of their co-workers on safety higher than other workers.

The three-factor analysis of variance for supervisory safety was highly significant $(F(28,261)=21.38, p<$ $.001)$. The main effects of education $(F(3,261)=146.24$, $p<.001)$, experience $(F(4,261)=26.33, p<.001)$ and job role $(F(1,261)=10.76, p<.001)$ were all highly significant, indicating that the higher-educated, more experienced and subjects in the role of supervisors thought more often than other groups that supervisors had a positive role in the safety. However, the interaction effect of these three factors was not significant $(F(3,261)=0.46$, n.s. $)$. The analysis of management safety practices by the three-factor analysis of variance was highly significant $(F(27,260)=10.53, p<$ $.001)$. The main effects of education $(F(3,260)=69.22$, $p<.001)$ and experience $(F(4,260)=11.81, p<.001)$ were highly significant, indicating that the higher-educated and more experienced workers valued highly the contribution of management towards safety. The main effect of job role $(F(1,260)=0.57$, n.s. $)$ and the interaction effect of three factors (education, experience and job role) $(F(2,260)=$ 1.88 , n.s.) were not statistically significant.

For safety programs, the three-factor analysis of variance was highly significant $(F(27,218)=16.55, p<.001)$. The main effects of education $(F(3,218)=112.85, p<$ $.001)$ and work experience $(F(4,218)=23.36, p<.001)$ were highly significant: the higher-educated and experienced workers considered the company's safety programs as more effective than the other workers. However, the main effect of job role $(F(1,218)=0.95$, n.s. $)$ and the interaction effect of all three factors $(F(2,218)=0.60$, n.s. $)$ were not significant. A three-factor analysis of variance for compliance was highly significant $(F(27,218)=13.34, p<$ $.001)$. The main effects of education $(F(3,218)=83.77$, $p<.001)$ and job experience $(F(4,218)=22.95, p<.001)$ were highly significant, indicating that the higher-educated 
Table 2

Work experience of Ghanaian industrial workers by education

\begin{tabular}{lcclc}
\hline $\begin{array}{l}\text { Work } \\
\text { experience }\end{array}$ & \multicolumn{4}{l}{ Educational level } \\
\cline { 2 - 5 } & $\begin{array}{l}\text { Basic } \% \\
(n=76)\end{array}$ & $\begin{array}{l}\text { Secondary } \% \\
(n=114)\end{array}$ & $\begin{array}{l}\text { Professional } \% \\
(n=122)\end{array}$ & $\begin{array}{l}\text { University } \% \\
(n=8)\end{array}$ \\
\hline $1-12$ months & 51 & 1 & 2 & 0 \\
1-4 years & 34 & 34 & 3 & 25 \\
5-10 years & 6 & 41 & 11 & 25 \\
11-14 years & 4 & 18 & 44 & 25 \\
15+ years & 5 & 6 & 40 & 25 \\
Total & 100 & 100 & 100 & 100 \\
\hline
\end{tabular}

$\chi^{2}=242.66, \mathrm{df}=12, p<.001$.

and more experienced workers were more compliant with the organization's safety policies. However, the main effect of job role $(F(1,218)=0.10$, n.s. $)$ and the interaction effect of all three factors $(F(2,218)=0.70)$ were not significant.

The three-factor analysis of variance for job satisfaction was highly significant $(F(28,259)=11.33, p<0.001)$. All three main effects for education $(F(3,259)=71.74$, $p<.001)$, job role $(F(1,259)=14.81, p<.001)$ and experience $(F(4,259)=14.05, p<.001)$ were also highly significant. The higher-educated workers, the more experienced, and supervisors expressed relatively higher levels of job satisfaction. However, the interaction effect was not significant $(F(3,259)=1.48$, n.s. $)$. Regarding accident frequency, the three-factor analysis of variance was also highly significant $(F(28,254)=15.45, p<.001)$. The main effects of education $(F(3,254)=104.44, p<.001)$ and experience $(F(4,254)=23.03, p<.001)$ were highly significant, indicating that the higher-educated and more experienced workers were less often involved in occupational accidents than the other workers. The main effect of job role $(F(1$, $254)=0.01$, n.s.) was not significant. The interaction effect of the three factors (education, experience and job role) was almost significant $(F(3,254)=2.72, p<.05)$. In a sum, all eight analyses indicted highly significant differences. The main effect of education was notably highly significant in all eight analyses and were stronger than the main effect of experience, which was also significant in all eight analyses. The main effect of job role and the interaction effect of three factors were significant only in two cases out of eight analyses.

Third, a posterior $t$-test consistently revealed significant differences between the two higher-educated cohorts and their lower-educated counterparts (see Table 4). The higher-educated workers, compared to their lower-educated counterparts, evaluated their workplace as more safe $(t=12.21, \mathrm{df}=296, p<.001)$, saw their co-workers $(t=$ $-11.31, \mathrm{df}=287, p<.001)$, their supervisors $(t=-13.23$, $\mathrm{df}=302, p<.001)$, and management as more committed to safety $(t=-10.73, \mathrm{df}=300, p<.001)$, were more satisfied with the safety program $(t=-12.28, \mathrm{df}=255, p<$ $.001)$, more satisfied with their job $(t=-8.27$, df $=299$, $p<.001$ ), were themselves more compliant with safety work procedures $(t=-9.89, \mathrm{df}=255, p<.001)$, and experienced less accidents in the last 12 months $(t=11.50$, $\mathrm{df}=295, p<.001)$

\section{Discussion}

This current study investigated the impact of education on workplace safety perceptions by comparing four educationally categorized groups. It also examined the relationships between education, job satisfaction, compliance with safety management policies, and accident frequency. The major finding was an association between workers' educational level and safety perception. The higher-educated workers expressed more positive perceptions regarding safety than their lower-educated counterparts. A dissection of this group revealed fascinating findings: workers with vocational/professional educational background were the most enthusiastic about the safety programs; followed by their counterparts with university education. When compared with their higher-educated colleagues with university education, workers with vocational/professional education who have had formal education and training in occupational health and safety related matters expressed the highest level of safety perception. They had the best scores on most of the subscales on the WSS: co-worker safety, supervisor safety, management safety practices and safety programs. Additionally, they displayed the highest levels of safety compliance and subsequently, had the lowest recorded accident involvement rate. Ostensibly, it wasn't general education that mattered most, but knowledge in specialized areas related to occupational safety. Workers with basic education were the least enthusiastic with the safety programs in their workplaces.

Two possible explanations could be offered for this observation. Apparently, the higher-educated workers who were most often considered as permanent staff, had received safety-related training and therefore had greater knowledge and skill regarding appropriate safety behaviours. They had the relevant occupational knowledge and experience in the very specific organizational context within which the hazards were encountered, and had displayed acumen and prudence in their ability to recognise situational contingencies, carefully appraised them and avoided disaster. Second, by dint of their educational status, the higher-educated workers had gained seniority and moved to safer jobs that rarely exposed them to the hazards their relatively lower-educated counterparts encountered. As anticipated, the finding supported a positive association between educational level and job satisfaction. The higher-educated, particularly, the university graduates were the most satisfied with workplace conditions. They were mostly in the middle or top management and assigned to more cognitively challenging jobs. Field work experience and interactions revealed that they had relatively more supportive work conditions with equitable rewards, access to fringe benefits and recreational facilities: conditions known 
Table 3

Descriptive statistics on workplace safety scale and educational level

\begin{tabular}{|c|c|c|c|c|c|c|c|c|c|}
\hline \multirow[t]{2}{*}{ Educational level } & \multicolumn{2}{|c|}{ Basic $(n=159)$} & \multicolumn{2}{|c|}{ Secondary $(n=98)$} & \multicolumn{2}{|c|}{ Professional $(n=56)$} & \multicolumn{2}{|c|}{ University $(n=7)$} & \multirow[t]{2}{*}{$p$} \\
\hline & $M$ & Std & $M$ & Std & $M$ & Std & $M$ & Std & \\
\hline A. Work safety & \multicolumn{8}{|c|}{$F(3,297)=68.12, p<.001$} & \\
\hline 1. Dangerous & 3.77 & 1.49 & 2.79 & 1.48 & 1.75 & 1.23 & 2.50 & 1.51 & $* * *$ \\
\hline 2. Safe & 2.04 & 1.47 & 2.86 & 1.42 & 3.92 & 1.22 & 3.36 & 1.51 & $* * *$ \\
\hline 3. Hazardous & 3.16 & 1.56 & 2.66 & 1.41 & 1.65 & 1.08 & 2.63 & 1.30 & $* * *$ \\
\hline 4. Risky & 3.59 & 1.56 & 2.68 & 1.43 & 1.50 & 0.73 & 2.00 & 0.76 & $* * *$ \\
\hline 5. Unhealthy & 3.64 & 1.51 & 2.60 & 1.27 & 1.54 & 0.80 & 2.13 & 0.99 & $* * *$ \\
\hline 6. Could get hurt & 3.69 & 1.43 & 2.73 & 1.39 & 1.47 & 0.84 & 1.88 & 0.35 & $* * *$ \\
\hline 7. Unsafe & 3.84 & 1.27 & 2.83 & 1.48 & 1.61 & 0.79 & 1.88 & 0.64 & $* * *$ \\
\hline 8. Fear for health & 3.61 & 1.42 & 2.75 & 1.49 & 1.56 & 0.76 & 1.88 & 0.64 & $* * *$ \\
\hline 9. Chance of death & 3.55 & 1.50 & 2.58 & 1.37 & 1.35 & 0.67 & 1.50 & 0.53 & $* * *$ \\
\hline 10. Scary & 3.60 & 1.37 & 2.66 & 1.37 & 1.47 & 0.71 & 1.50 & 0.53 & $* * *$ \\
\hline B. Co-worker safety & \multicolumn{8}{|c|}{$F(3,288)=54.51, p<.001$} & \\
\hline 1. Ignore safety rules & 3.25 & 1.21 & 2.80 & 1.09 & 1.71 & 0.87 & 2.25 & 0.46 & $* * *$ \\
\hline 2. Do not care about other's safety & 3.22 & 1.42 & 2.56 & 1.18 & 1.77 & 1.07 & 2.38 & 1.06 & $* * *$ \\
\hline 3. Pay attention to safety rules & 2.51 & 1.23 & 3.13 & 1.15 & 3.69 & 1.11 & 3.63 & 0.92 & $* * *$ \\
\hline 4. Follow safety rules & 2.42 & 1.29 & 3.25 & 1.25 & 4.33 & 0.85 & 3.75 & 1.04 & $* * *$ \\
\hline 5. Look out for others' safety & 2.46 & 1.38 & 3.38 & 1.37 & 4.41 & 0.76 & 4.00 & 1.07 & $* * *$ \\
\hline 6. Encourage others to safety & 2.24 & 1.03 & 3.04 & 1.16 & 4.05 & 0.75 & 3.00 & 0.93 & $* * *$ \\
\hline 7. Take chances with safety & 3.63 & 1.03 & 3.53 & 1.06 & 2.55 & 1.17 & 2.14 & 0.92 & $* * *$ \\
\hline 8. Keep work area clean & 2.34 & 1.19 & 2.92 & 1.15 & 3.93 & 0.77 & 3.87 & 0.64 & $* * *$ \\
\hline 9. Safety-oriented & 2.30 & 1.31 & 3.18 & 1.33 & 4.24 & 0.98 & 3.86 & 1.26 & $* * *$ \\
\hline 10. Do not pay attention & 2.26 & 0.98 & 2.63 & 1.10 & 2.45 & 1.15 & 2.86 & 1.36 & ns \\
\hline C. Supervisor safety & \multicolumn{8}{|c|}{$F(3,303)=85.20, p<.001$} & \\
\hline 1. Praise safe work behaviour & 2.61 & 0.79 & 3.24 & 0.92 & 3.92 & 0.76 & 3.83 & 0.83 & $* * *$ \\
\hline 2. Encourages safe behaviours & 2.17 & 0.87 & 3.20 & 1.52 & 4.09 & 0.83 & 3.75 & 1.16 & $* * *$ \\
\hline 3. Keep workers informed on safety rules & 2.11 & 1.01 & 3.05 & 1.17 & 4.41 & 0.85 & 3.75 & 0.71 & $* * *$ \\
\hline 4 Rewards safe behaviours & 1.91 & 1.07 & 2.64 & 1.12 & 3.91 & 0.97 & 3.75 & 0.89 & $* * *$ \\
\hline 5. Involves workers in setting safety goals & 2.01 & 1.11 & 2.77 & 1.25 & 4.06 & 0.85 & 3.75 & 1.28 & $* * *$ \\
\hline 6. Discusses safety issues with others & 2.14 & 1.11 & 2.92 & 1.29 & 4.15 & 0.82 & 3.75 & 0.89 & $* * *$ \\
\hline 7. Updates safety rules & 2.14 & 1.02 & 3.08 & 1.30 & 4.23 & 0.83 & 3.50 & 1.07 & $* * *$ \\
\hline 8. Trains workers to be safe & 2.01 & 1.12 & 3.26 & 1.32 & 4.22 & 0.81 & 3.63 & 1.19 & $* * *$ \\
\hline 9. Enforces safety rules & 2.16 & 1.19 & 3.20 & 1.39 & 4.37 & 0.74 & 3.75 & 0.89 & $* * *$ \\
\hline 10. Acts on safety suggestions & 2.20 & 1.29 & 3.37 & 1.32 & 4.42 & 0.74 & 3.62 & 1.19 & $* * *$ \\
\hline D. Management safety practices & \multicolumn{8}{|c|}{$F(3,301)=53.10, p<.001$} & \\
\hline 1. Provides enough safety program & 2.13 & 1.00 & 2.87 & 0.99 & 3.42 & 0.98 & 3.62 & 1.06 & $* * *$ \\
\hline 2. Conducts frequent safety inspections & 1.77 & 0.85 & 2.37 & 1.00 & 2.93 & 1.12 & 3.00 & 1.41 & $* * *$ \\
\hline 3. Investigates safety problems & 1.68 & 0.877 & 2.34 & 0.94 & 2.91 & 1.06 & 3.25 & 1.04 & $* * *$ \\
\hline 4. Rewards safe workers & 1.81 & 0.84 & 2.19 & 0.94 & 2.78 & 1.08 & 3.00 & 1.19 & $* * *$ \\
\hline 5. Provides safe equipment & 1.86 & 0.91 & 2.55 & 1.12 & 3.36 & 0.93 & 3.50 & 0.53 & $* * *$ \\
\hline 6. Provides safe working conditions & 1.87 & 0.92 & 2.63 & 1.09 & 3.49 & 0.96 & 3.75 & 0.70 & $* * *$ \\
\hline 7. Responds to safety concerns & 1.99 & 0.86 & 2.71 & 1.14 & 3.65 & 1.09 & 3.38 & 1.06 & *** \\
\hline 8. Helps maintain clean area & 2.00 & 1.13 & 2.71 & 1.26 & 3.75 & 1.08 & 3.50 & 1.07 & $* * *$ \\
\hline 9. Provides safety information & 2.13 & 1.14 & 3.00 & 1.34 & 3.87 & 1.12 & 3.63 & 0.74 & $* * *$ \\
\hline 10. Keep workers informed of hazards & 2.13 & 1.21 & 2.99 & 1.34 & 3.85 & 1.19 & 3.25 & 1.04 & $* * *$ \\
\hline E. Safety programs (policies) & \multicolumn{8}{|c|}{$F(3,245)=51.32, p<.001$} & \\
\hline 1. Worthwhile & 2.29 & 1.29 & 3.23 & 1.14 & 4.26 & 0.86 & 3.88 & 1.25 & $* * *$ \\
\hline 2. Helps prevent accidents & 2.07 & 1.09 & 2.91 & 1.28 & 4.24 & 0.84 & 3.71 & 1.26 & $* * *$ \\
\hline 3. Useful & 1.87 & 1.29 & 2.93 & 1.45 & 4.42 & 0.66 & 4.00 & 1.00 & $* * *$ \\
\hline 4. Good & 1.83 & 1.23 & 2.95 & 1.48 & 4.41 & 0.80 & 3.71 & 0.75 & $* * *$ \\
\hline 5. First-rate & 1.84 & 1.15 & 2.78 & 1.33 & 4.23 & 0.74 & 3.43 & 0.79 & $* * *$ \\
\hline 6. Unclear & 3.22 & 1.11 & 2.66 & 1.09 & 1.19 & 1.31 & 2.58 & 1.28 & $* * *$ \\
\hline 7. Important & 1.96 & 1.19 & 2.88 & 1.37 & 4.00 & 0.84 & 3.71 & 1.25 & $* * *$ \\
\hline 8. Effective in reducing injuries & 1.96 & 1.22 & 2.03 & 1.45 & 4.16 & 0.82 & 3.57 & 0.78 & $* * *$ \\
\hline 9. Do not apply to my workplace & 3.50 & 1.12 & 2.05 & 1.07 & 1.10 & 1.31 & 1.94 & 1.23 & $* * *$ \\
\hline 10. Do not work & 3.86 & 1.17 & 2.22 & 1.04 & 1.67 & 1.33 & 1.32 & 1.47 & ** \\
\hline
\end{tabular}

Note. Scores on work safety were in reverse order. n.s., no statistical significance.

${ }_{* * *}^{* *} p<.10$.

*** $p<.001$. 
Table 4

Descriptive statistics on Work Safety Scale (WSS), safe work behaviour, accident frequency and educational level

\begin{tabular}{|c|c|c|c|c|c|c|c|c|c|}
\hline \multirow[t]{2}{*}{ Educational level } & \multicolumn{2}{|c|}{ Basic $(n=159)$} & \multicolumn{2}{|c|}{ Secondary $(n=98)$} & \multicolumn{2}{|c|}{ Professional $(n=56)$} & \multicolumn{2}{|c|}{ University $(n=7)$} & \multirow[t]{2}{*}{$p$} \\
\hline & $M$ & Std & $M$ & Std & $M$ & Std & $M$ & Std & \\
\hline Work safety & $36.51_{\mathrm{a}}$ & 11.27 & $27.44_{\mathrm{a}}$ & 11.98 & $15.91_{\mathrm{b}}$ & 6.08 & $10.50_{\mathrm{b}}$ & 4.95 & $* * *$ \\
\hline Co-worker safety & $26.26_{\mathrm{a}}$ & 7.44 & $30.92_{\mathrm{a}}$ & 7.11 & $37.87_{b}$ & 3.99 & $34.75_{\mathrm{b}}$ & 5.33 & $* * *$ \\
\hline Supervisor commitment & $21.49_{\mathrm{a}}$ & 8.74 & $30.73_{\mathrm{a}}$ & 10.58 & $41.59_{b}$ & 5.72 & $37.13_{\mathrm{b}}$ & 9.63 & $* * *$ \\
\hline Management commitment & $19.37 \mathrm{a}$ & 7.37 & $26.29 \mathrm{a}$ & 8.86 & $34.00_{\mathrm{b}}$ & 7.25 & $33.89_{\mathrm{b}}$ & 8.43 & $* * *$ \\
\hline Satisfaction w. programs & $25.14_{\mathrm{a}}$ & 6.61 & $26.83_{\mathrm{a}}$ & 7.86 & $38.42_{b}$ & 5.03 & $31.93_{\mathrm{b}}$ & 3.43 & $* * *$ \\
\hline Job Satisfaction & $2.00_{\mathrm{a}}$ & 1.23 & $3.14_{\mathrm{a}}$ & 1.29 & $4.11_{\mathrm{b}}$ & 0.98 & $4.38_{\mathrm{b}}$ & 0.75 & $* * *$ \\
\hline Compliance & $11.99 \mathrm{a}$ & 5.25 & $15.68_{\mathrm{a}}$ & 5.13 & $20.41_{b}$ & 3.23 & $18.25_{b}$ & 4.17 & $* * *$ \\
\hline Accident frequency & $2.93_{\mathrm{a}}$ & 0.97 & $1.98_{\mathrm{a}}$ & 1.07 & $1.09_{b}$ & 0.37 & $1.12_{\mathrm{b}}$ & 0.79 & $* * *$ \\
\hline
\end{tabular}

Note. Scores on work safety were in reverse order. Means with different subscripts in the same row are significantly different $=p<.001$.

to facilitate job satisfaction (e.g., Herzberg et al., 1975), but denied their lower-educated counterparts.

Explanation for the positive association between educational level and compliance with safe work could be gleaned from the Social Exchange (Blau, 1964) and Reciprocity Theory (Gouldner, 1960). According to these theories, workers who perceive a high level of organizational support tend to feel a sense of indebtedness and a need to reciprocate in terms that benefit their organizations. Such reciprocals have included pro-social organizational behaviours that have been considered as facilitative of their organizational goal attainment. As a means of reciprocity for the privileges and the organizations' recompense, the higher-educated workers were thus motivated to comply with the organization's safety management policies. The current observation thus supports the social exchange theory and the norms of reciprocity as a basis of workers' safety-related behaviours (e.g., Gyekye and Salminen, 2007; Hofmann et al., 2003) and pro-social organizational behaviours (e.g., Gyekye and Salminen, 2005; Rhoades and Eisenberger, 2002). The observed link could also be explained by the fact that as protagonists and enforcers of the safety rules, the higher-educated workers had been motivated to comply with the organization's safe work procedures to manifest themselves as responsible role models. Additionally, it is also on record that workers are more motivated to comply with safety policies when they possess the requisite knowledge in the very specific organizational context within which the hazards were encountered (Probst, 2002). Thus, the higher-educated workers, by dint of their educational background and knowledge, had been more compliant with safety management policies than their lower-educated counterparts.

The results data show a negative relationship with educational level and accident frequency. From the above explanations, it is perceptible that the higher the educational background, the lower the risk exposure was, and vice versa. Unlike their higher-educated colleagues, the lowereducated workers were mostly causal or temporary workers called to fill the gap. In such cases, even cursory training in relevant procedures and equipment were lacking, and little organizational effort had been expended on their selection and placements regarding their capabilities to perform effec- tively their allocated tasks. With comparatively less normative knowledge, the lower-educated workers, particularly those with only basic education, were at a greater risk of displaying inappropriate and inaccurate safety behaviours. Plausibly, they might have misunderstood and violated more the organizational safety policies. More so, this category of workers often do accept hazardous tasks and work under considerable stressful conditions, such as job and income insecurity, low earnings, excessive time pressure, lack of job variety and interest, lack of control over work, and inability to raise workplace issues and concerns: all of which are factors that presumably led to the negative perceptions regarding workplace safety and increased their vulnerability to accidents (e.g., Probst and Brubaker, 2001). Meanwhile, the job content of the higher-educated does not have the same conflicting demands.

On the whole, the current findings are consistent with studies that have found a substantial positive relationship between cognitive abilities and job performance (e.g., Ghiselli, 1966; Hunter, 1986; Reason, 1997). They are also supportive of earlier studies that have shown workers with the requisite knowledge on safe work behaviours to have displayed greater compliance with the organizations safety management policies and subsequently registered relatively fewer accidents (Elangovan et al., 2005; Hodson et al., 2004; Probst, 2002). At the end of the day, safe work behaviour requires to some extent accurate hazard perception, correct risk appraisals, all of which are dependent, one way or the other, on education and training.

\subsection{Safety implications and directions for further studies}

The high accident involvement rate by lower-educated workers, particularly those with basic education signals a need for special safety programs specifically designed for them. An integrated approach of education, enforcement and engineering controls will best protect them from accidents and injuries. Effective safety education programs in conjunction with the appropriate leadership role (e.g., corrective leadership, supervisory safety practices) can induce positive safety behaviours onto subordinate workers on the shop level (Zohar, 2002a,b). Support for this argument is 
drawn from Zohar's recent studies in which supervisory monitoring and prioritizing safety over competing goals (2002a), and corrective leadership (2002b) provided complementary modes of influence on safety behaviour. Legal measures could be put in place to enforce companies to offer safety courses to lower-educated temporary workers. Additionally, management could invest in making their organizations more satisfying and safe. They could do this by implementing fairness perception measures (Shore and Shore, 1995; Simons and Robertson, 2003), create job enrichment programs (Godard, 2001) and provide support to workers beyond what is formally stated in the contractual agreement (Aryee et al., 2002; Shore and Shore, 1995). These measures would increase worker job-satisfaction, add to organizational efficiency and productivity and positively influences safety practices. Ultimately, it would decrease accident frequency and thereby reduce the high human and social costs associated with industrial accidents.

The primary strength of this study is its empirical disposition. Participants were authentic workplace workers. The findings therefore complement previous experimental and laboratory research suggesting a link between cognitive abilities, job performance, and safety outcomes (e.g., Hunter, 1986; Probst, 2002). It is however limited by its reliance on self-reported instruments. The possibility thus exists for the findings to be distorted by participants' desire to respond in a consistent manner. However, recent meta-analytic research by Crampton and Wagner (1994) indicates that while this problem continues to be cited regularly, the magnitude of distortions may be overestimated. Selfreported measures have been effectively used in accident and safety analyses (e.g., Gyekye, 2005, 2006; Siu et al., 2003). Besides, while epidemiologic reports have been found to be faulty, biased and deficient because of poor documentation (Parker et al., 1994; Veazie et al., 1994), research reports have found self-reported accident rates to be closely related to documented accident rates (Smith et al., 2001). Notwithstanding the above-mentioned limitation, the current study contributes to the growing body of research which has identified educational status as important variable for investigation in safety management policies.

\section{References}

Aryee, S., Budhwar, P., Chen, Z., 2002. Trust as a mediator of the relationship between organizational justice and work outcomes: test of a social exchange model. Journal of Organizational Behavior 23, 267285 .

Blau, P., 1964. Exchange and Power in Social Life. Wiley, New York.

Blau, P., Duncun, O.D., 1967. The American Occupational Structure. Wiley, New York.

Carder, B., Ragan, P.W., 2003. A survey-based system for safety measurement and improvement. Journal of Safety Research, 157-165.

Cooper, M.D., Phillips, R.A., 2003. Exploratory analysis of the safety climate and safety behaviour. Journal of Safety Research 35, 497-512.

Crampton, S.M., Wagner, J.A., 1994. Percept-percept inflation in micro organizational research: an investigation of prevalence and effect. Journal of Applied Psychology 79, 67-76.
DeJoy, D., Murphy, L., Gershon, R., 1995. Safety climate measure in health care settings. In: Bitent, A.C., Champney, P.C. (Eds.), . In: Advances in Industrial Ergonomics and Safety, vol. 7. Taylor \& Francis, London, pp. 923-929.

DeJoy, D., Schaffer, B., Wilson, M., Vandenberg, R., Butts, M., 2004. Creating safer workplaces: assessing the determinants and role of safety climate. Journal of Safety Research 35, 81-90.

Diaz, R., Cabrera, D., 1997. Safety climate and attitude as evaluation measures of organizational safety. Accident Analysis and Prevention $29,643-650$.

Döös, M., Backström, T., Sundström-Frisk, C., 2004. Human actions and errors in risk handling - an empirically grounded discussion of cognitive action-regulation levels. Safety Science 42 (3), 185-204.

Dunnette, M.D., 1976. Aptitudes, abilities, and skills. In: Dunnette, M.D. (Ed.), Handbook of Industrial and Organizational Psychology. Rand, Chicago, pp. 473-520.

Elangovan, R.K., Mohammed, K.P., Mohan, S., 2005. Effectiveness of the designed safety education programme modules by their implementation in selected industries. Journal of Loss Prevention in the Process Industries 18 (4-6), 553-557.

Ghiselli, E.E., 1966. The Validity Of Occupational Aptitude Tests. Wiley, New York

Godard, J., 2001. High performance and the transformation of work: the implications of alternative work practices for the future of Canadian IR research. Industrial Relations 56, 3-33.

Gordon, M., Arvey, R., 1975. The relationship between education and satisfaction with job content. Academy of Management Journal 18, 888-892.

Gouldner, A.W., 1960. The norm of reciprocity. American Sociological Review 25, 161-178.

Guastello, S.J., 1999. Injury analyses and prevention in the developing countries. Accident Analysis and Prevention 31, 295-296.

Gyekye, A.S., 2005. Workers' perceptions of workplace safety and job satisfaction. International Journal of Occupational Safety and Ergonomics 11, 291-302.

Gyekye, A.S., 2006. Workplace safety perceptions: miners' and nonminers' perspectives. Professional Safety 7, 34-40.

Gyekye, A.S., Salminen, S., 2005. Are good soldiers safety conscious? An examination of the relationship between Organizational Citizenship Behaviors and perceptions of workplace safety. Social Behavior and Personality: An International Journal 33 (8), 805-820.

Gyekye, A.S., Salminen, S., 2006. Making sense of industrial accidents: the role of job satisfaction. Journal of Social Sciences 2 (4), 127134.

Gyekye, A.S., Salminen, S., 2007. Workplace safety perceptions and Perceived Organizational Support: do supportive perceptions influence safety perceptions? International Journal of Occupational Safety and Ergonomics 13 (2), 103-114.

Harter, J., Hayes, T., Schmidt, F., 2002. Business-unit level relationship between employee satisfaction, employee engagement, and business outcomes. A meta-analysis. Journal of Applied Psychology 87, 268279.

Hansen, C.P., 1989. A causal model of the relationship among accidents, biodata, personality and cognitive factors. Journal of Applied Psychology 74, 81-90.

Hayes, B., Perander, J., Smecko, T., Trask, J., 1998. Measuring perceptions of workplace safety: development and validation of the work safety scale. Journal of Safety Research 29, 145-161.

Herzberg, F., Mausner, B., Peterson, P., Capwell, F., 1975. Job Attitudes: Review of Research and Opinion. Psychological Service of Pittsburgh, Pittsburgh, PA.

Hodson, M., Lapenta, D., Rogers, S., Nace, N., 2004. Hand in hand: an interdisciplinary team approach to education improves compliance in an Acute Rehabilitation Setting American. Journal of Infection Control 32 (3), 104-105.

Hofmann, D., Stetze, A., 1998. The role of safety climate and communication in accident interpretations: implications for learning from negative events. Academy of Management Journal 41, 644-657. 
Hofmann, D., Morgeson, F., Gerras, S., 2003. Climate as a moderator of the relationship between leader-member exchange and content specific citizenship: safety climate as an exemplar. Journal of Applied Psychology 88 (1), 170-178.

Howard, J., Frink, D., 1996. The effects of organizational restructure on employee satisfaction. Group and Organizational Management 21, 278-303.

Hunter, J.E., 1986. Cognitive ability, cognitive aptitudes, job knowledge, and job performance. Journal of Vocational Behaviour 29, 340-362.

Iverson, R.D., Erwin, P.J., 1997. Predicting occupational injury: the role of affectivity. Journal of Occupational and Organizational Psychology 70, 113-128.

Kanfer, K., Ackerman, P., 1989. Motivational and cognitive abilities: an integrative aptitude-treatment interaction approach to skill acquisition. Journal of Applied Psychology 74, 657-690.

Klien, S., Maher, J., 1966. Educational level and satisfaction with pay. Personnel Psychology 19, 195-208.

King, M., Murray, M., Atkinson, T., 1982. Background personality, job characteristics and satisfaction with work in a national sample. Human Relations 35, 119-133.

Lourens, P., Vissers, J., Jessurun, M., 1999. Annual mileage, driving violations and accident involvement in relations to drivers' sex, age, and level of education. Accident Analaysis and Prevention 31, 593 597.

Metle, M.K., 2003. The impact of education on attitudes of female government employees. Journal of Management Development 22 (7), 603-626.

Niskanen, T., 1994. Safety climate in the road administration. Safety Science 17, 237-255.

Oshagbemi, T., 2003. Personal correlates of job satisfaction: empirical evidence from UK universities. International Journal of Social Economics 30 (12), 213-226.

O'Toole, B.I., 1990. Intelligence and behaviour and motor vehicle accident mortality. Accident Analysis and Prevention 22 (3), 211-221.

Owsley, C., McGwin, G., Phillips, J.M., 2004. Impact of an educational program on the safety of high-risk, visually impaired, older drivers. American Journal of Preventive Medicine 26, 222-229.

Parker, D., Carl, W., French, L., Martin, F., 1994. Characteristics of adolescent work injuries reported in Minnesota Department of Labour and Industry. American Journal of Public Health 84, 606-611.

Porter, L., Lawler III, E., 1968. Managerial Attitudes and Performance. Irwin-Dorsey, Home-wood, IL.

Probst, T.M., 2002. Layoffs and tradeoffs: production, quality, and safety demands under the threat of job loss. Journal of Occupational Health Psychology 7, 211-220.
Probst, T., Brubaker, T., 2001. The effects of job insecurity on employee safety outcomes: cross-sectional and longitudinal explorations. Journal of Occupational Health Psychology 6, 139-159.

Prussia, G., Brown, K., Geoff, P., 2003. Mental models of safety: do managers and employees see eye to eye? Journal of Safety Research 34 (2), 143-156.

Reason, J., 1997. Managing the Risks of Organizational Accidents. Ashgate, Aldershot.

Rhoades, L., Eisenberger, R., 2002. Perceived organizational support: a review of the literature. Journal of Applied Psychology 87, 698-714.

Shore, L., Shore, T., 1995. Perceived organizational support and organizational justice. In: Cropanzano, R., Kacmar, K. (Eds.), Organizational Politics, Justice, and Support. Quorum Books, CT. pp. 149-164.

Silva, S., Lima, L.M., Baptista, C., 2004. OSCI: an organisational and safety climate inventory. Safety Science 42, 205-220.

Simons, T., Robertson, Q., 2003. Why managers should care about fairness: the effect of aggregate justice perception on organizational outcomes. Journal of Applied Psychology 88, 432-443.

Smith, C.S., Silverman, G.S., Heckert, T.M., Brodke, M., Hayes, B., Silverman, M.K., Mattimore, L.K., 2001. A comprehensive method for the assessment of industrial injury events. Journal of Prevention \& Intervention in the Community 22, 5-20.

Siu, O.L., Phillips, D., Leung, T., 2003. Age differences in safety attitudes and safety perceptions in Hong Kong construction workers. Journal of Safety Research 34, 199-205.

Veazie, K., Landen, D., Bender, T., Amandus, H., 1994. Epidemiological research on the aetiology of injuries at work. Annual Review of Public Health 15, 203-221.

Vollmer, J., Kinney, J., 1995. Age, education and job satisfaction. Academy of Management Journal 21, 265-274.

Wanous, P., Reichers, A., Hody, M., 1997. Overall job satisfaction. How good are single-item measures? Journal of Applied Psychology 82, $147-252$.

Zohar, D., 1980. Safety climate in industrial organization: theoretical and applied implications. Journal of Applied Psychology 65, 96-102.

Zohar, D., 2002a. Modifying supervisory practices to improve sub-unit safety: a leadership-based intervention model. Journal of Applied Psychology 87, 156-163.

Zohar, D., 2002b. The effects of leadership dimensions, safety climate, and assigned priorities on minor injuries in work groups. Journal of Organizational Behaviour 23, 75-92.

Zohar, D., Luria, G., 2003. The use of supervisory practices as leverage to improve safety behaviour: a cross-level intervention model. Journal of Safety Research 34, 567-577. 